\title{
ULTRASTRUCTURE AND MORPHOMETRY OF OVARIAN FOLLICLES IN THE ARMADILLO Chaetophractus villosus (MAMMALIA, DASYPODIDAE)
}

\author{
CODÓN, S. M., ${ }^{1}$ ESTECONDO, S. G., ${ }^{1}$ GALÍNDEZ, E. J. ${ }^{1}$ and \\ CASANAVE, E. B. ${ }^{2}$ \\ ${ }^{1}$ Laboratorio de Histología Animal \\ ${ }^{2}$ Laboratorio de Fisiología Animal y Conicet \\ Departamento de Biología, Bioquímica y Farmacia, Universidad Nacional del Sur, San Juan 670, 8.000 - \\ Bahía Blanca, Argentina \\ Correspondence to: Dra. Stella Maris Codón, Departamento de Biología, Bioquímica y Farmacia, \\ Universidad Nacional del Sur, San Juan 670, 8.000 - Bahía Blanca, Argentina, e-mail: smcodon@criba.edu.ar \\ Received September 23, 1999 - Accepted June 9, 2000 - Distributed August 31, 2001
}

(With 20 figures)

\begin{abstract}
Ultrastructural and morphometric changes in oocyte and surrounding granulosa cells during armadillo follicular growth are described. Primordial, intermediary, early and late primary, secondary, tertiary and preovulatory Graafian follicles were found. From primordial to Graafian follicle, granulosa cells increase in height, become multilayered while fluid-filled spaces arise among them in the tertiary follicle stage. As the follicle expands the oocyte is located eccentrically and grows in size. From primordial to secondary stage organelles develop in number and complexity and many vesicles start arising in the cytoplasm at the secondary stage. From tertiary follicle stage the number of mitochondria decreases. In follicular cells, secreting-related organelles expand, but mitochondrial number decreases according to the follicle expansion. Intercellular junctions between both cell types increase. The morphometrical study shows a biphasic pattern of oocyte and follicle growth. The morphological baseline here provided will be essential for further comprehension of the reproductive biology in armadillos.
\end{abstract}

Key words: ovarian follicles, armadillo, Chaetophractus villosus, Dasypodidae, reproduction.

\section{RESUMO}

\section{Ultra-estrutura e morfometria dos folículos ováricos no tatu Chaetophractus villosus (Mammalia, Dasypodidae)}

São descritas a ultra-estrutura e as mudanças morfométricas nos ovócitos e nas células da granulosa durante o crescimento folicular do tatu. Foram encontrados folículos primordiais, intermediários, primários (iniciais e finais), secundários, terciários e folículos de Graff pré-ovulatórios. Desde os folículos primordiais até os folículos de Graff, as células da granulosa aumentam de tamanho, dispõem-se em múltiplas camadas e, no folículo terciário, apresentam espaços cheios de líquido entre elas. Quando o folículo se expande, o ovócito localiza-se exentricamente e aumenta de tamanho. Nos folículos primários e secundários, as organelas desenvolvem-se aumentando em número e complexidade e, no folículo secundário, várias vesículas desenvolvem-se no citoplasma. A partir do folículo terciário, o número de mitocôndrias diminui. Nas células foliculares, as organelas relacionadas à secreção se expandem, mas o número de mitocôndrias diminui com a expansão do folículo. As uniões intercelulares entre ambos os tipos de células aumentam. Os estudos morfométricos mostram um padrão bifásico de crescimento do ovócito e do folículo. A informação morfológica deste trabalho pode ser de grande importância no entendimento da biologia reprodutiva dos tatus.

Palavras-chave: folículos ováricos, tatu, Chaetophractus villosus, Dasypodidae, reprodução. 


\section{INTRODUCTION}

Armadillos (Xenarthra, Dasypodidae) are neotropical eutherian mammals, with burrowing habits, grouped in nine genera and approximately twenty species (Redford \& Eisenberg, 1992). Only Dasypus novemcinctus has reached the southern region of the United States (Taulman \& Robbins, 1996).

Armadillos, and particularly Chaetophractus villosus, present certain unique features which make them suitable for biomedical research such as a remarkable adaptability to laboratory conditions, capability to endure serial cardiac bleedings for in vivo haematological investigations (Casanave \& Polini, 1999; Polini et al., 1999), a great development of olfactory neuroanatomical structures (García Samartino et al., 1987), relatively low body temperature (Casanave \& Affanni, 1994), high resistance to hypoxia (Affanni et al., 1986, 1987) and low metabolic rate (Mc Nab, 1984).

Genus Dasypus is well-known for its specific polyembryony (Fernández, 1909; Newman \& Patterson, 1909) and D. novemcinctus has been used as an animal model for some human diseases, particularly leprosy (Kirchheimer \& Storrs, 1971). In spite of both the zoological and biomedical importance of the group (Storrs, 1971), there is scarce morphological information about Dasypodidae.

Knowledge about female reproductive tract is limited to D. novemcinctus (Talmage \& Buchanan, 1954; Enders \& Buchanan, 1959; Enders, 1960, 1966; Peppler \& Canale, 1980). As regards $C$. villosus, only brief references about female reproductive features have been made (Grassé, 1955; Raynaud, 1969) and the histology of the ovary has been described by Codón \& Casanave (1996). The scarcity of information on the reproductive features renders its use in laboratory difficult. In addition, the phylogenetic position of the armadillos, very close to the metatheria-eutheria split (Engelmann, 1985), reveals them as a primitive eutherian group whose oocyte and follicle growth are particularly interesting to investigate.

The aim of this work is to attempt an understanding of the reproductive biology of $C$. villosus by studing the stages of development of its ovarian follicles from the morphometrical, microanatomical and ultrastructural point of view.

\section{MATERIAL AND METHODS}

Twenty two adult females weighing between 2.8 and $3.7 \mathrm{~kg}$ were trapped alive every month in the Bahía Blanca area (province of Buenos Aires, Argentina). Immediately after the animals were euthanized with $75 \mathrm{mg} / \mathrm{kg}$ sodium thiopentate i.p., ovaries were dissected out. For light microscopy, they were processed by standard techniques and stained with hematoxylin-eosin or Masson's trichrome.

For transmission electron microscopy (TEM) small pieces of ovaries were fixed in $2.5 \%$ glutaraldehyde in $0.1 \mathrm{M}$ cacodylate buffer for 12 hours and postfixed in $1 \%$ osmium tetroxide in the same buffer for 1 hour. Fixation was carried out at $4^{\circ} \mathrm{C}$. They were then dehydrated in graded acetone and infiltrated in low density resin. The ultrathin sections were contrasted with uranyl acetate and lead citrate and observed with a JEOL CX II transmission electron microscope.

For the morphometric study, two diameters of 81 healthy follicles and oocytes were measured at right angles in serial consecutive sections and the highest value of each structure was used. Mean values of oocyte and follicle diameters were calculated at each stage of development. Follicles in the intermediary stages were not measured because they are scarce and can only be well defined with electron microscopy. Since there was an important variation between the mean diameters, logarithmic transformation was applied. Statistical differences between means were calculated by Analysis of Variance (ANOVA). The mean diameters were compared with Tukey-Cramer's test. Correlation between follicle and oocyte diameters was calculated using linear regression analysis (Sokal \& Rohlf, 1981).

\section{RESULTS}

The stages of ovarian follicles identified were: primordial, intermediary, early primary, late primary, secondary, tertiary and Graafian or preovulatory.

Primordial follicle. The oocyte is surrounded by flat follicular cells which are either isolated or in a complete layer. It is round with a large, spherical, slightly eccentric and euchromatic nucleus. Abundant rounded or oval-shaped mitochondria, with a few arched cristae, are uniformly scattered. They are larger than those of the 
surrounding follicular cells (Figs. 1 and 2). Microtubules and rounded multivesicular bodies (Fig. 1) are observed but Balbiani bodies were not found. Rough endoplasmic reticulum (REG) is not abundant but there are many free ribosomes and polyribosomes. Golgi complexes are well-developed (Fig. 2).

In early stages the oocyte has a smooth surface and there are desmosome junctions between oocyte and follicular cells (Figs. 1 and 3 ).

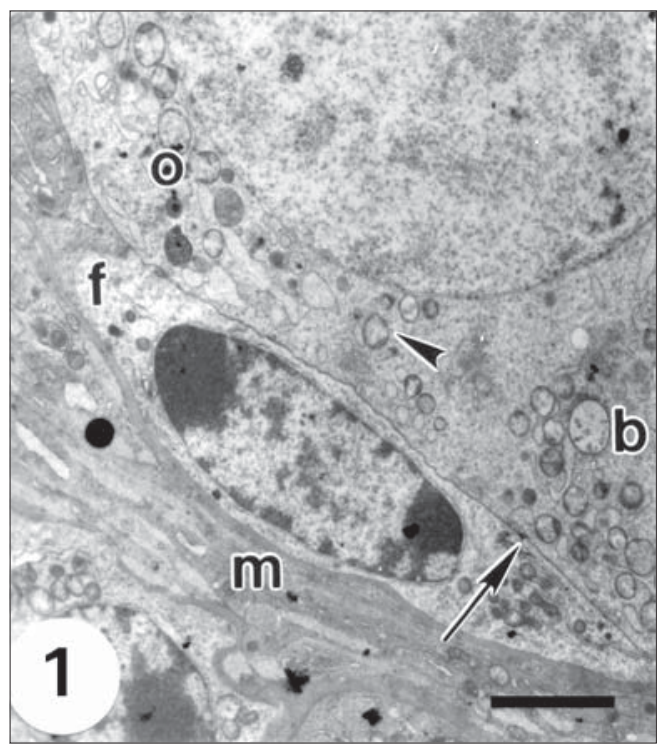

Fig. 1 - Primordial follicle in the ovary of Chaetophractus villosus showing an oocyte (o) encircled by an incomplete layer of flattened follicular cells (f) on the basement membrane $(\mathrm{m})$. In the oocyte there are multivesicular bodies (b), mitochondria (arrowhead) as well as desmosome (arrow) between oocyte and follicular cells. Bar $=2.5 \mu \mathrm{m}$.

With the formation of a complete layer of granulosa cells, some microvilli project from the follicular cells (Fig. 2). Follicular cells are squamous with a large, flat-shaped and heterochromatic nucleus (Figs. 1 and 2). Granular endoplasmic reticulum is scarce. Mitochondria are generally rounded, with dense matrices and a few cristae (Fig. 2).

Intermediary follicle. Squamous follicular cells are intermingled with cuboidal cells (Fig. 4).
The features of the oocyte are comparable with those observed in the primordial follicle (Fig. $5)$. Follicular cells have a flattened or rounded heterochromatic nucleus (Fig. 4). In cuboidal cells REG appears in concentric rings.

Early primary follicle. The oocyte is entirely surrounded by a single layer of cuboidal follicular cells. It has a large, spherical and somewhat eccentric euchromatic nucleus (Fig. 6). Cytoplasmic features are similar to those of previous stages.



Fig. 2 - A region of a primordial follicle where the oocyte (o) is entirely surrounded by one layer of flattened follicular cells (f). Note granular endoplasmic reticulum, REG, (r), Golgi complex $(\mathrm{G})$ and mitochondrias (arrowhead) in the oocyte (o); microvilli (arrow) between oocyte and follicular cells; REG (r) and mitochondrias (arrowhead) in the follicular cells (f) and the basement membrane $(\mathrm{m})$. Bar $=2.0 \mu \mathrm{m}$.

In some zones there is a close association between follicular cells and the oocyte (Figs. 7 and 8), while elsewhere there are dilated intercellular spaces traversed by cytoplasmic projections from 
both cellular types (Fig. 9) sometimes forming junctional complexes.

Follicular cells have a large, rounded heterochromatic nucleus and scarce cytoplasm. Paranuclear Golgi complexes are well-developed (Fig. 7). Dilated REG vesicles are often associated with mitochondria (Fig. 9).

Late primary follicle. Follicular cells increase in height and they are still organised in one layer (Fig. 10). The features of the oocyte are comparable to those of previous stages.

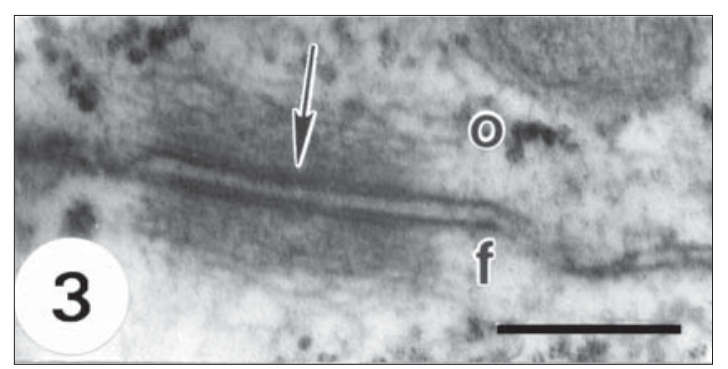

Fig. 3 - High magnification of the plasmalemma of a follicular cell (f) and the oolemma (o) in a primordial follicle showing a desmosome (arrow). Bar $=0.25 \mu \mathrm{m}$.

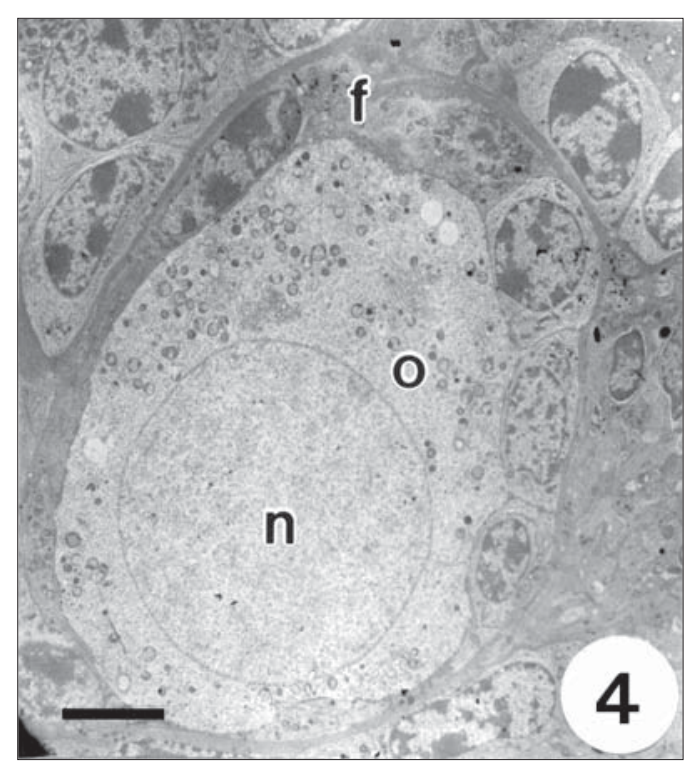

Fig. 4 - General view of an intermediary follicle showing the oocyte (o) encircled by one layer of both flattened and cuboidal follicular cells (f) intermingled. Note the slightly eccentric nucleus (n). Bar $=5.0 \mu \mathrm{m}$.
In some zones of the intercellular space between the follicular cells and the oocyte there are microvilli from both cellular types while in other zones first traces of zona pellucida material appear (Fig. 11).

Junctional complexes are more abundant than in the early primary follicle. Follicular cells are columnar with a spherical, heterochromatic and basal nucleus (Fig. 10).

There are many rounded mitochondria, REG appears as isolated vesicles or in supranuclear concentric rings (Fig. 11).

Secondary follicle. With two or more layers of cuboidal follicular cells without intercellular spaces (Fig. 12). In the oocyte the nucleus is large, rounded and euchromatic.

There are abundant vesicles and multivesicular bodies (Fig. 13). A striking difference with previous stages is the presence of a wider zona pellucida with a homogeneous matrix containing an increased number of microvilli of the oocyte and follicular cells (Fig. 14).

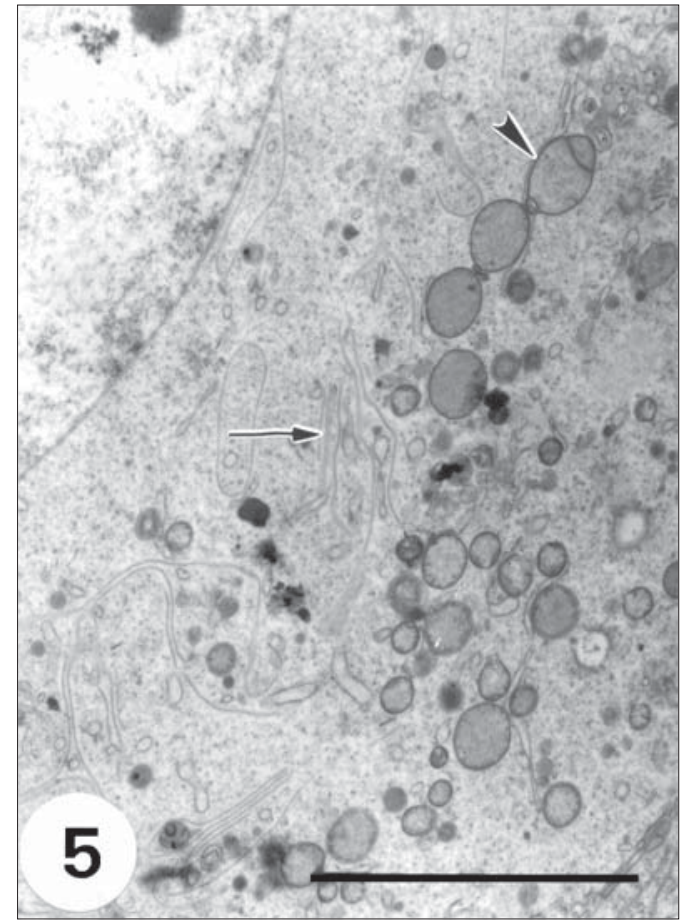

Fig. 5 - Mitochondria (arrowhead) and microtubules (arrow) of the oocyte in an intermediary follicle. Bar $=5.0 \mu \mathrm{m}$. 


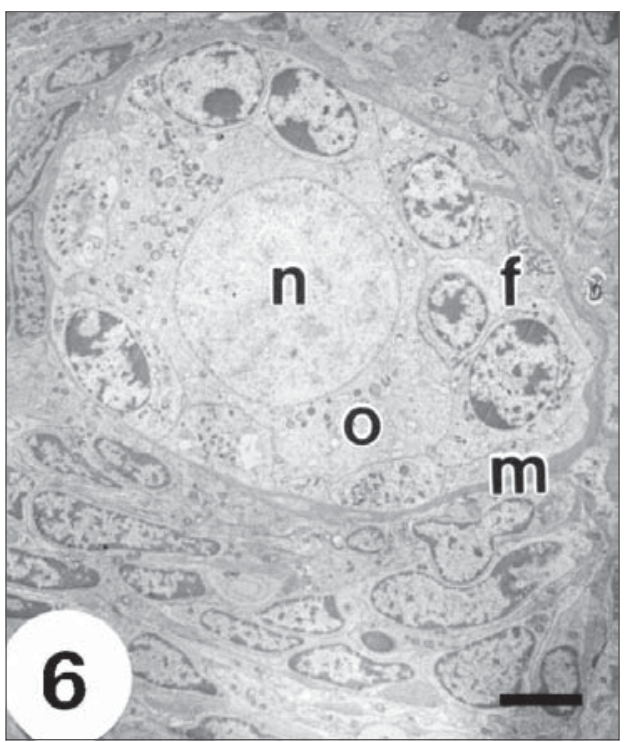

Fig. 6 - General view of an early primary follicle with cuboidal follicular cells (f) on a basement membrane (m), surrounding the oocyte (o). Note the nucleus (n) located slightly off centre. Bar $=5.0 \mu \mathrm{m}$.

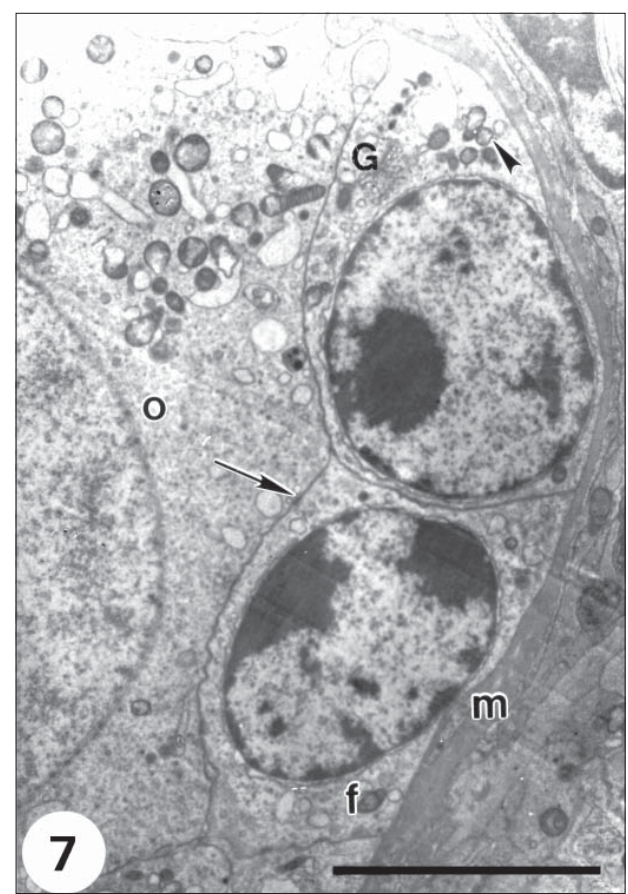

Fig. 7 - High magnification of a region of an early primary follicle showing the close association (arrow) between the oocyte (o) and follicular cells (f) resting on the basement membrane $(\mathrm{m})$. Note Golgi complex $(\mathrm{G})$ and mitochondria (arrowhead) in the follicular cells. Bar $=5.0 \mu \mathrm{m}$.

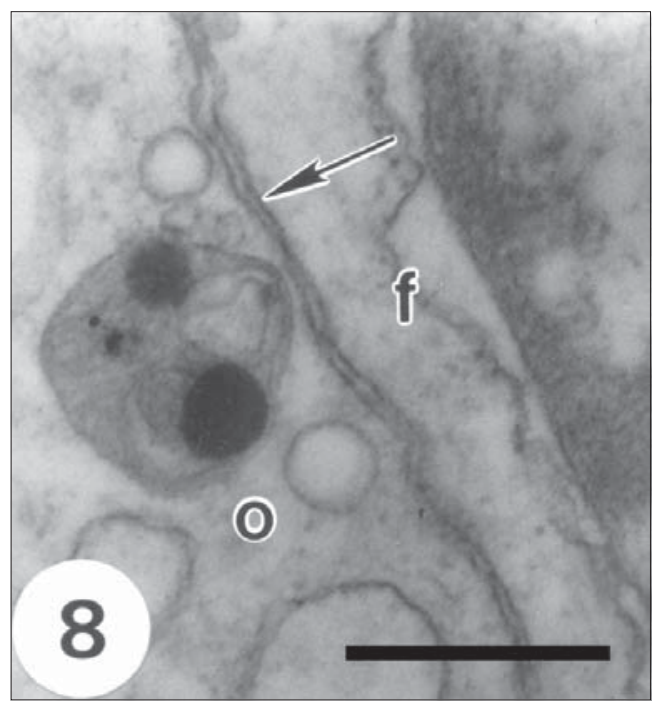

Fig. 8 - Detailed area of the close association (arrow) between follicular cells (f) and oocyte (o) in an early primary follicle. Note a multivesicular body in the oocyte. Bar $=0.5 \mu \mathrm{m}$.

The nucleus of the follicular cells is large, oval-shaped, often indented and heterochromatic (Fig. 12). Golgi complexes are highly developed and are in supranuclear or paranuclear position.

Dilated cisternae of REG, and sometimes concentric profiles can still be seen. A thin sheath of fibroblast-like cells of the theca interna surrounds the follicular epithelium (Fig. 12).

Tertiary follicle. Fluid-filled spaces are distinguished between follicular cells (Fig. 15), which are arranged in stratified concentric layers.

The granulosa cells in contact with the basement membrane, form a compact layer (Fig. 16).

The nucleus of the oocyte is eccentric. In the cytoplasm there are few mitochondria, multivesicular bodies and microtubules, but abundant vesicles, ribosomes and polyribosomes (Fig. 17).

Hooded mitochondria were not found. The follicular cells have large, heterochromatic, usually round-shaped nuclei and scarce cytoplasm (Figs. 15 and 16). Scant, rounded mitochondria are comparable with those described in previous stages (Fig. 15). Granular endoplasmic reticulum (Fig. 15) and Golgi complex are extensive.

There are electron-dense granules and vacuoles (Figs. 15 and 16). 


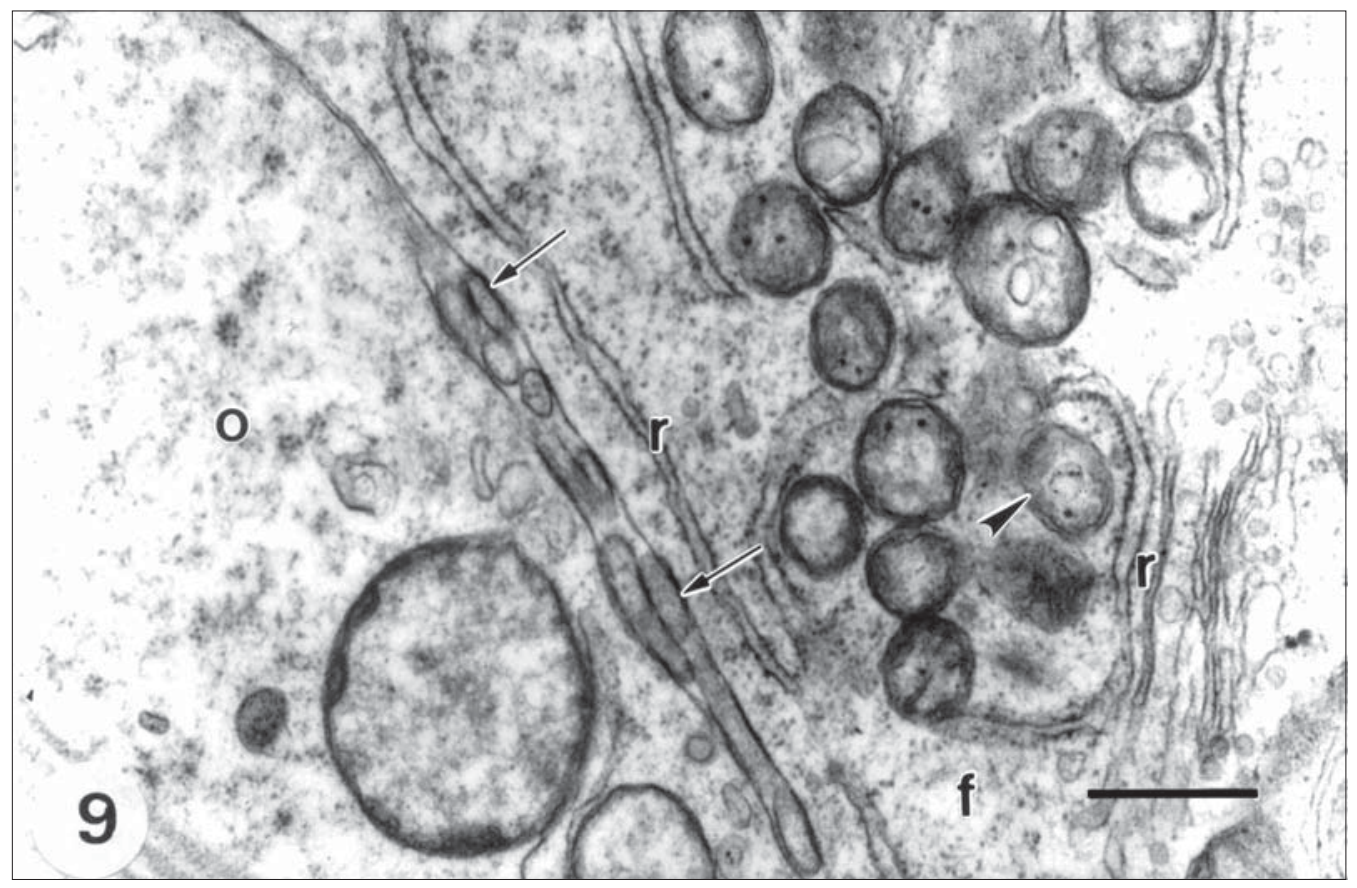

Fig. 9 - Section through a region of oocyte (o) and follicular cell (f) in an early primary follicle showing microvilli (arrow) between both cell types, as well as mitochondria (arrowhead) and REG (r) in the follicular cells. Bar $=0.5 \mu \mathrm{m}$.

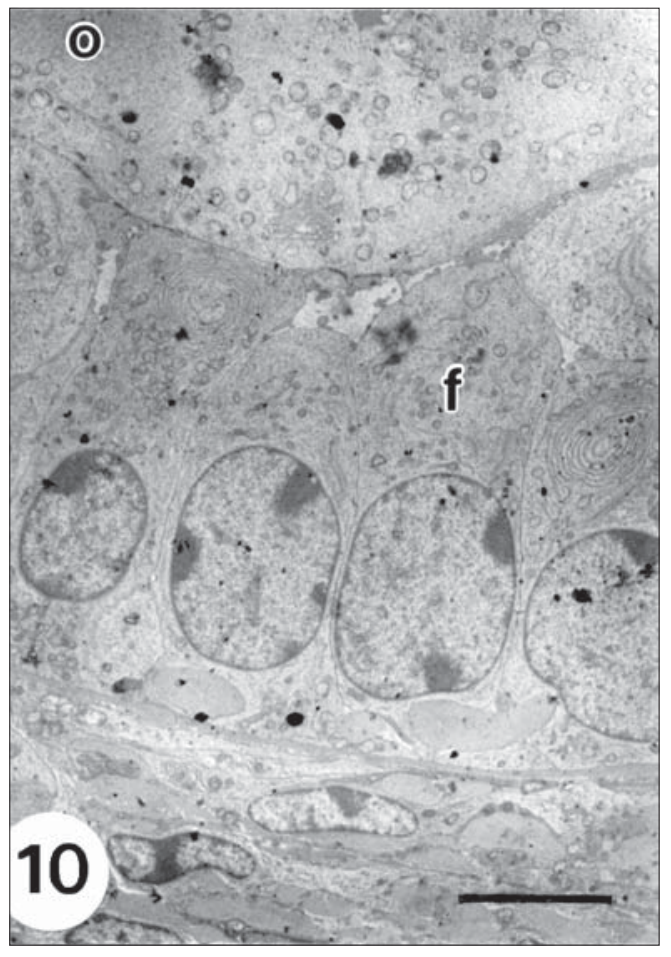

Fig. 10 - Late primary follicle with one layer of columnar follicular cells (f) surrounding the oocyte (o). Bar $=5.0 \mu \mathrm{m}$.

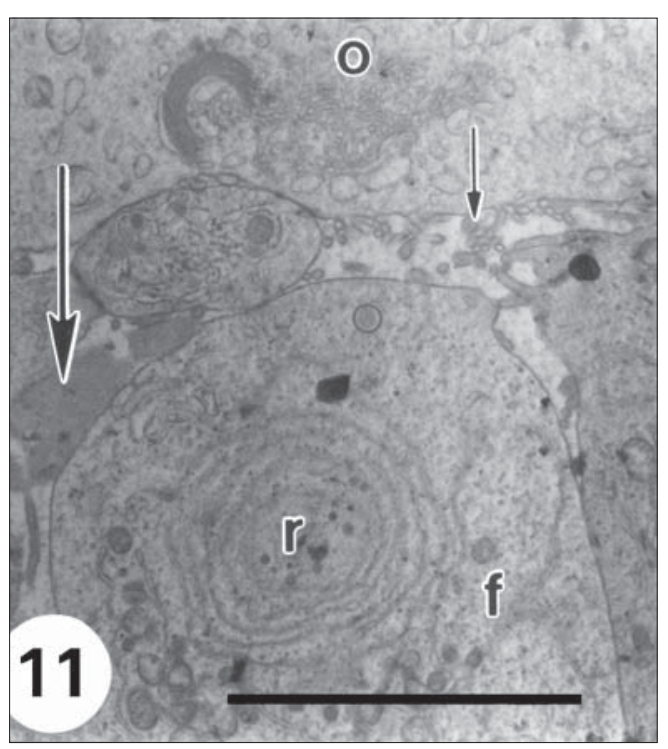

Fig. 11 - High magnification of an area of Fig. 10 showing patches of zona pellucida (big arrow) and microvilli (arrow), between the oocyte (o) and the follicular cells (f) and concentric rings of REG (r) in the follicular cells. Bar $=5.0 \mu \mathrm{m}$. 


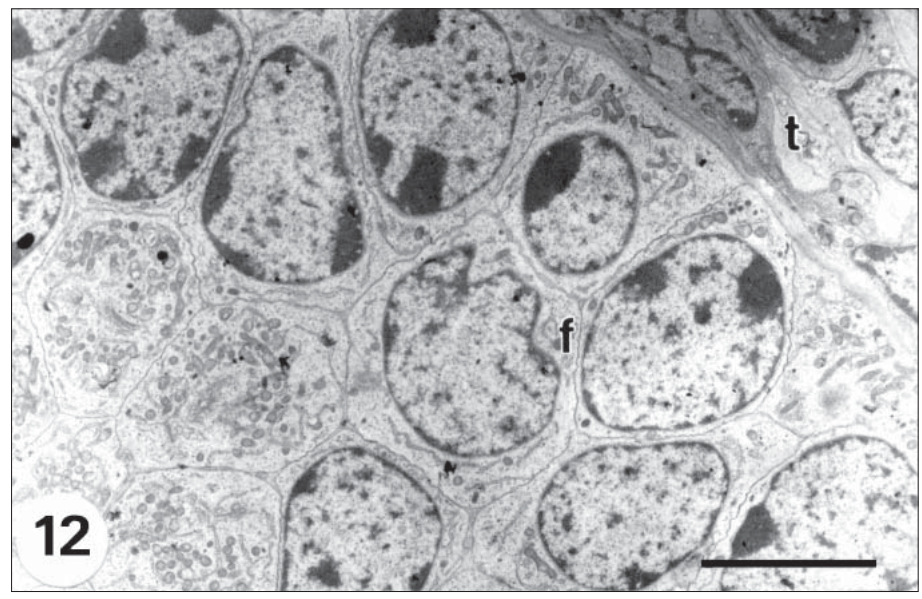

Fig. 12 - Secondary follicle with several layers of follicular cells (f) surrounded by the theca layer (t). Bar $=5.0 \mu \mathrm{m}$.

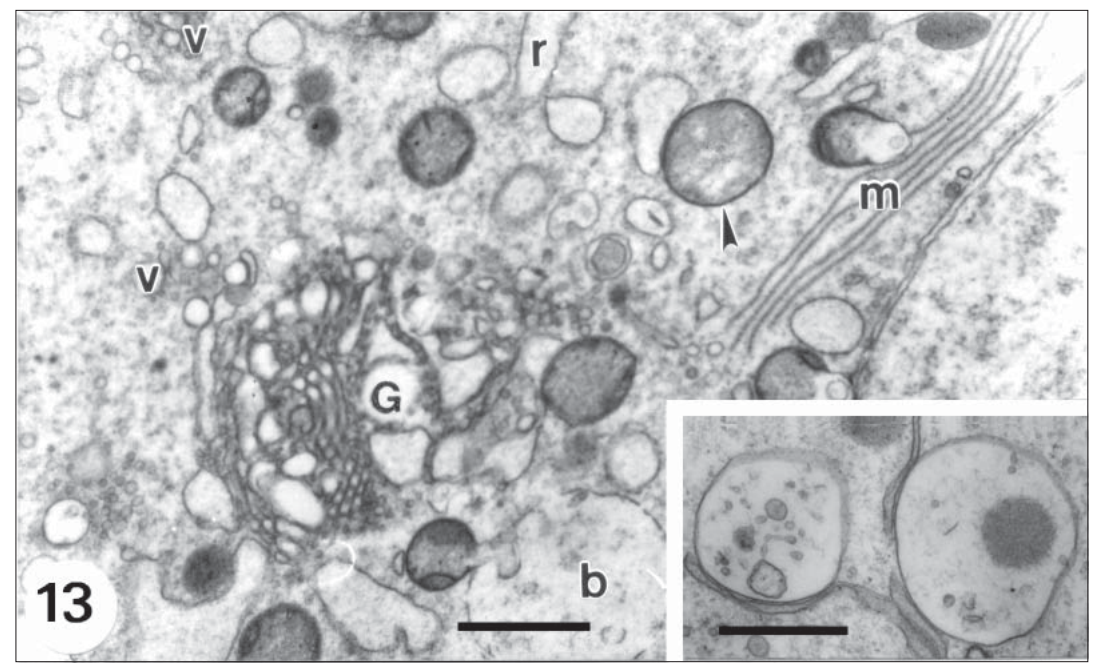

Fig. 13 - Area of the oocyte in a secondary follicle with multivesicular bodies (b), Golgi complex (G), REG (r), microtubules $(\mathrm{m})$, vesicles (v) and mitochondria (arrowhead). Bar $=1.0 \mu \mathrm{m}$. Inset: multivesicular bodies.

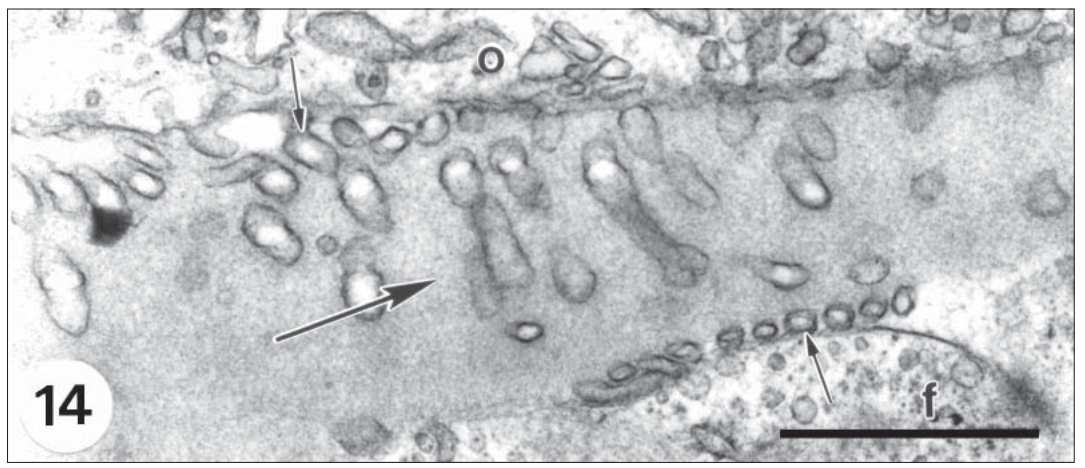

Fig. 14 - High magnification of an area between oocyte (o) and follicular cell (f) in a secondary follicle. Note microvilli (arrow) extending through the prominent zona pellucida (big arrow). Bar $=1.0 \mu \mathrm{m}$. 


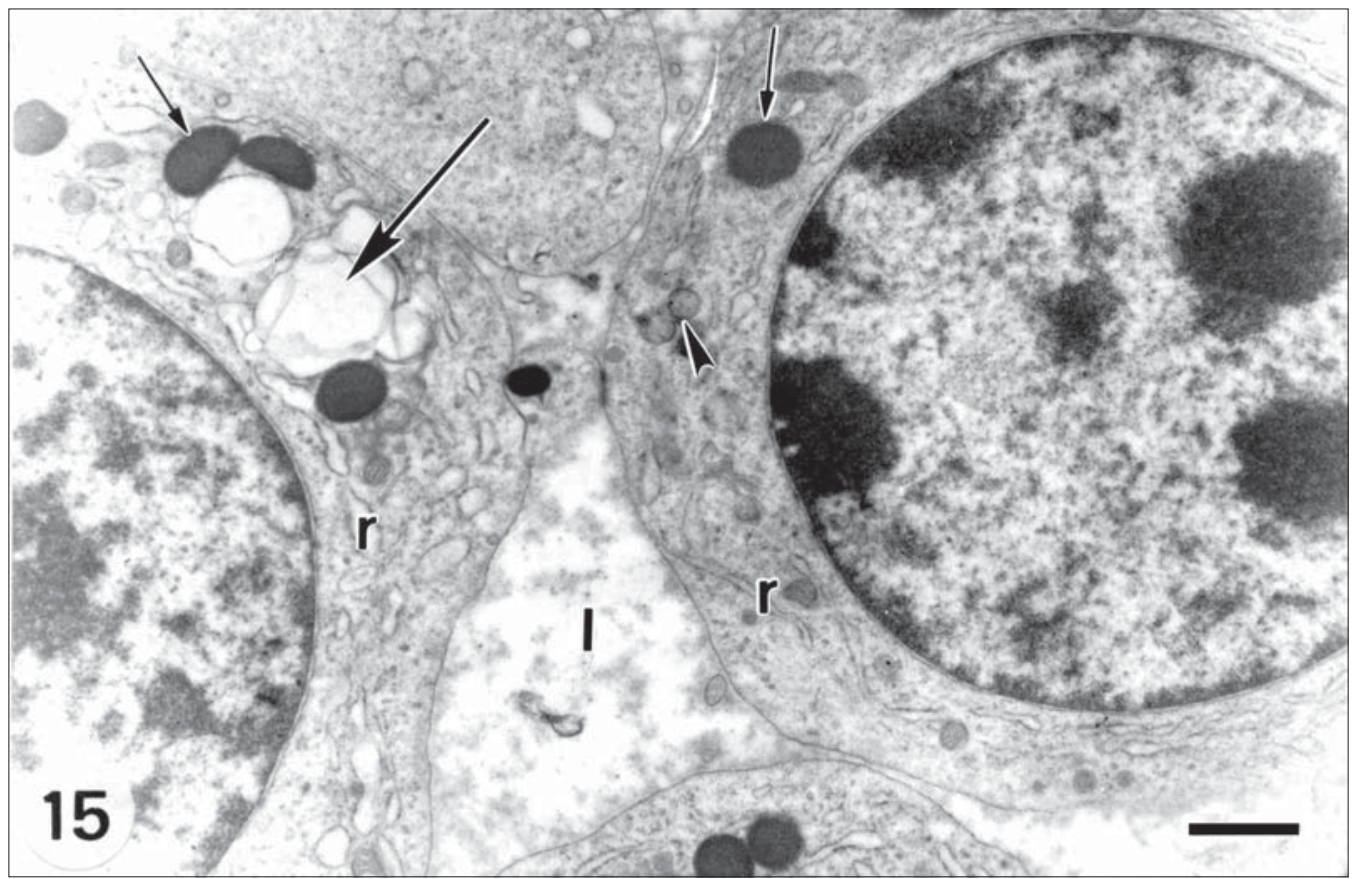

Fig. 15 - Follicular cells of the granulosa layer in a tertiary follicle showing lacunae (1) among them. Note electron-dense granules (arrow), vacuoles (big arrow), REG (r) and mitochondria (arrowhead). Bar $=1.0 \mu \mathrm{m}$.

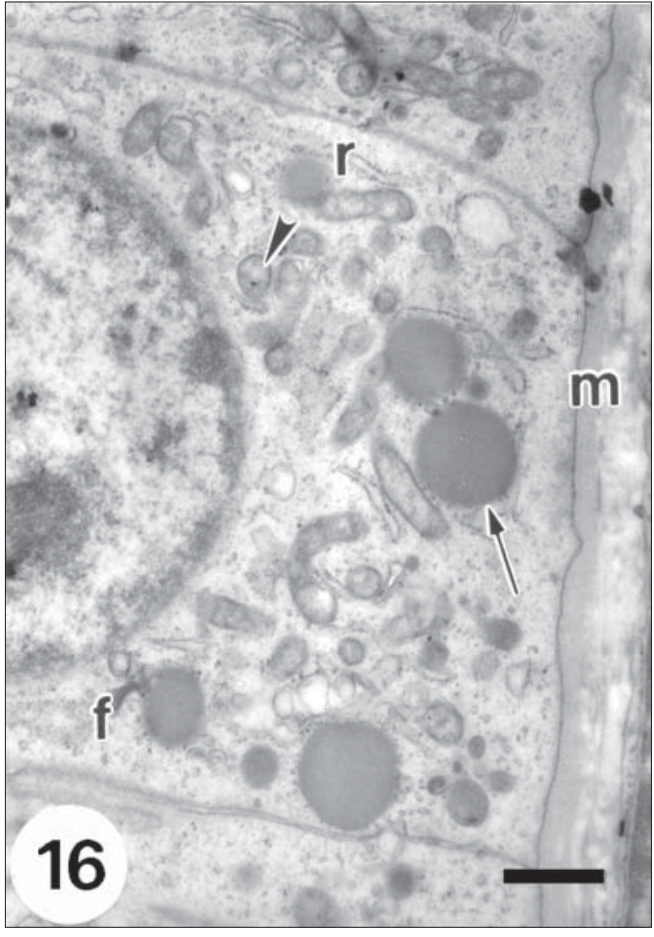

Fig. 16 - Follicular cells (f) in contact with the basement membrane $(\mathrm{m})$ forming a compact layer in a tertiary follicle. Note REG (r), mitochondrias (arrowhead) and electron-dense granules (arrow). Bar $=1.0 \mu \mathrm{m}$.
The theca differentiates into two layers. The theca interna is made up of flattened or spindleshaped fibroblast-like cells with a flattened nucleus and abundant elongated mitochondria. The theca externa is composed by longer cells with a more flattened nucleus.

Preovulatory follicle. It presents a single large cavity, the follicular antrum.

The oocyte, with a prominent zona pellucida, is displaced to a peripheral zone of the follicle. It has an eccentric nucleus. The layer of granulosa cells covering the antrum has uniform thickness except where it forms the cumulus oophorus which surrounds the oocyte, thus forming the corona radiata (Fig. 18).

The granulosa cells show a great number of electron-dense granules (Fig. 19).

Morphometry. There were differences between stages (Table 1) for follicles $(\mathrm{F}=391.9$, $\mathrm{p}<0.01)$ and oocytes $(\mathrm{F}=202.3, \mathrm{p}<0.01)$.

The tertiary follicle oocyte did not differ from the preovulatory one $(\mathrm{p}>>0.20)$. The growth of the oocyte and follicle conforms a biphasic pattern, reaching the oocyte the maximum development in the tertiary follicle stage.

A linear and positive correlation between oocyte diameter and follicle diameter was found 
$(\mathrm{R}=0.96)$. This model is applicable to all follicle stages, excepting the Graafian one (Fig. 20).

\section{DISCUSSION}

Follicular morphology in Dasypodidae is poorly known and this work is the first ultrastructural reference in the group.

The morphological characteristics here employed, such as the shape and disposition of granulosa cells and their number of layers, may be suitable to tipify follicles in Dasypodidae.

The identification of primordial follicles with an incomplete layer of granulosa cells in adult $C$. villosus, which corresponds to the small follicles type 2 of Pedersen \& Peters (1968), is a remarkable feature.

Although this fact differentiates the armadillo's ovary from the mouse's one, in which this sort of primordial follicles are found exclusively in

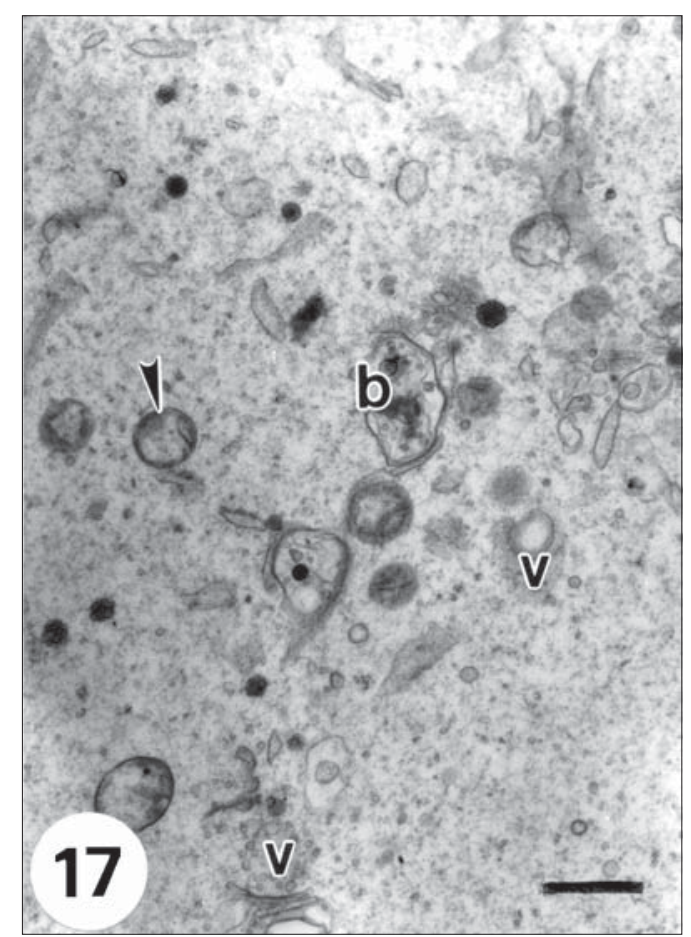

Fig. 17 - Section through a region of the oocyte of a tertiary follicle showing scarce mitochondria (arrowhead), vesicles (v) and multivesicular bodies (b). Bar $=1.0 \mu \mathrm{m}$. the prenatal stage (Wordinger et al., 1993), it resembles the ovary of other primitive mammals (Falconnier \& Kress, 1992; Maitland \& Ullmann, 1993).

The intermediary follicle corresponds to the one described by Motta et al. (1994), to type 3a or $3 b$ of Pedersen \& Peters (1968) or to an activated primordial follicle (Fair \& Hyttel, 1997; Fair et al., 1997).

The identification of early and late stages of primary follicle, both included in type $3 \mathrm{~b}$ of Pedersen \& Peters (1968), was supported by the increase of height of follicular cells and it probably indicates a rise in activity. The secondary, tertiary and preovulatory follicles here described coincide with those reported by Falconnier \& Kress (1992), Pedersen \& Peters (1968) and Wordinger et al. (1993). Fair \& Hyttel (1997) and Fair et al. (1997) have different criteria of classification for these follicles.

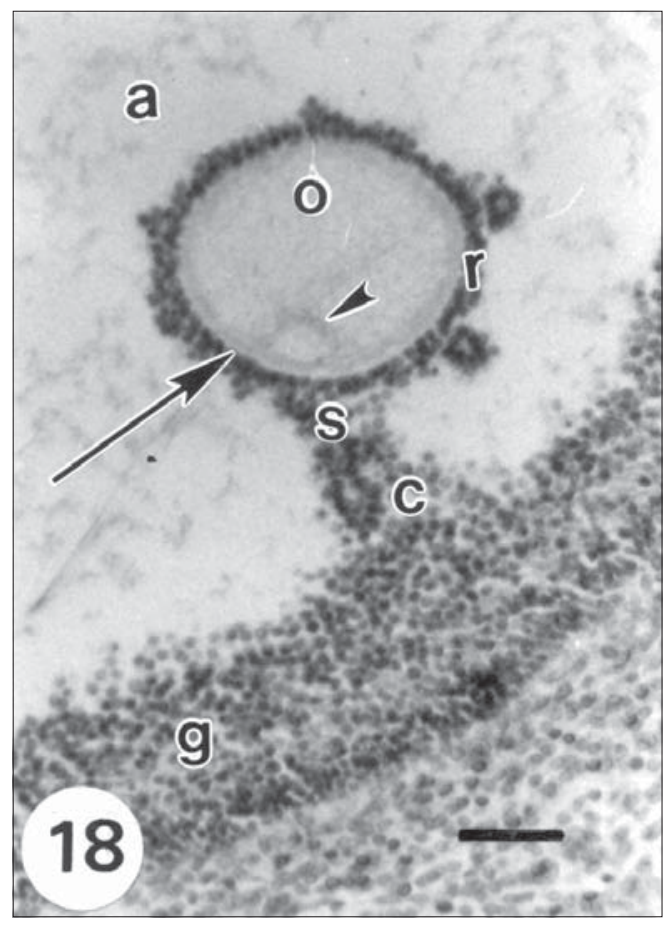

Fig. 18 - Light microscopy of a Graafian follicle showing the eccentric oocyte (o) with eccentric nucleus (arrowhead), in the follicular antrum (a), surrounded by the zona pellucida (arrow) and the corona radiata (r). Note the granulosa layer (g), the cumulus oophorus (c) and the stalk (s). Masson. Bar $=50 \mu \mathrm{m}$. 


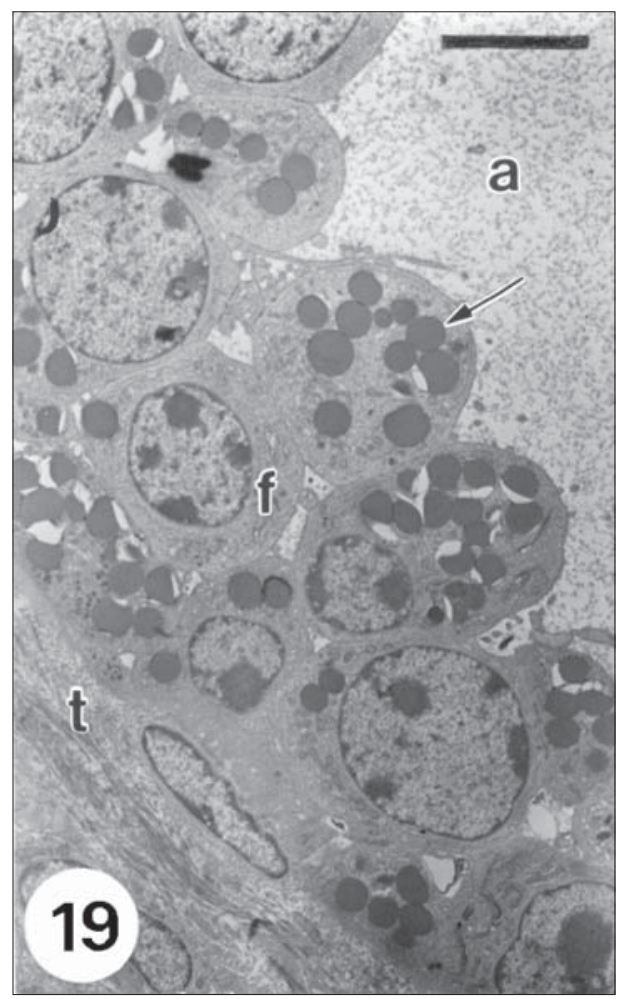

Fig. 19 - Follicular cells (f) of the granulosa layer surrounding the follicular antrum (a). Note electron-dense granules (arrow) and the theca layer (t). Bar $=5.0 \mu \mathrm{m}$.

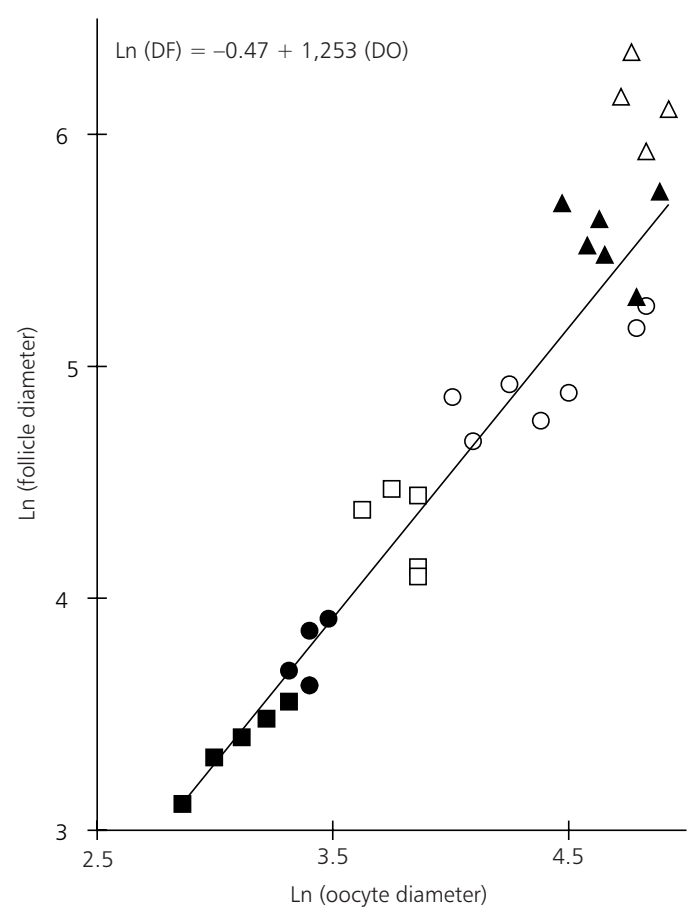

Fig. 20 - Follicle diameter (DF) plotted against oocyte diameter (DO) in each stage for $C$. villosus, showing positive and linear correlation between follicle and oocyte diameter. ( $\mathbf{\square}$ : primordial follicle; $\bullet$ : early primary follicle; $\square$ : late primary follicle; O: secondary follicle; $\mathbf{\Delta}$ : tertiary follicle and $\Delta$ : Graafian follicle).

TABLE 1

Mean diameters ( \pm SD) and ranges of oocytes and follicles in Chaetophractus villosus for each stage of development.

\begin{tabular}{|l|c|c|c|c|c|}
\hline \multirow{2}{*}{} & \multirow{2}{*}{$\mathbf{n}$} & \multicolumn{2}{|c|}{ Oocyte } & \multicolumn{2}{c|}{ Follicle } \\
\cline { 3 - 6 } & & Mean \pm SD & Range & Mean \pm SD & Range \\
\hline Primordial & 12 & $19.38 \pm 5.55^{\mathrm{a}}$ & $12.5-27.5$ & $28.13 \pm 5.01^{\mathrm{a}}$ & $22.5-37.5$ \\
\hline Early primary & 11 & $26.36 \pm 4.52^{\mathrm{b}}$ & $17.5-32.5$ & $38.64 \pm 5.85^{\mathrm{b}}$ & $30.0-50.0$ \\
\hline Late primary & 13 & $38.27 \pm 7.39^{\mathrm{c}}$ & $27.5-47.5$ & $71.00 \pm 12.97^{\mathrm{c}}$ & $47.5-87.5$ \\
\hline Secondary & 17 & $84.63 \pm 20.40^{\mathrm{d}}$ & $55.0-125.0$ & $134.52 \pm 25.45^{\mathrm{d}}$ & $105.0-192.5$ \\
\hline Tertiary & 17 & $122.79 \pm 18.35^{\mathrm{e}}$ & $87.5-143.8$ & $289.43 \pm 55.40^{\mathrm{e}}$ & $200.0-412.5$ \\
\hline Graafian & 11 & $131.71 \pm 13.30^{\mathrm{e}}$ & $112.5-153.8$ & $489.58 \pm 126.90^{\mathrm{f}}$ & $287.5-750.0$ \\
\hline
\end{tabular}

SD: standard deviation.

All measurements are in $\mu \mathrm{m}$.

Different superscripts letters indicate significantly different $(\mathrm{p}<0.01)$.

The morphological features of the mitochondria in the oocyte agree with those described for Monodelphis (Falconnier \& Kress, 1992), although their shape does not change with the growth of the oocyte and hooded mitochondria were not found (Fair \& Hyttel, 1997; Fair et al., 1997). Their uniform distribution in all stages suggests the absence of peripheral migration during the oocyte growth referred to in other mammals (Falconnier \& Kress, 1992; Motta et al., 1995; Fair \& Hyttel, 1997; Fair et al., 1997). Furthermore, the greater size of mitochondria of the oocyte in relation to 
that of the surrounding follicular cells in all stages is a noticeable feature in C. villosus, since a declining in size has been described in the primordial follicle in other species (Falconnier \& Kress, 1992).

The pattern of the remainder organelles in each stage of the oocyte is similar to the one in Monodelphis and other mammals (Falconnier \& Kress, 1992) but differs from the bovine's (Fair \& Hyttel, 1997; Fair et al., 1997). The absence of Balbiani bodies has also been reported in Monodelphis and suggests a relation with the evolutionary position of these animals. Whereas the stage in which the zona pellucida appears coincides with that of the armadillo Dasypus novemcinctus (Enders \& Buchanan, 1959) and Monodelphis (Falconnier \& Kress, 1992), it differs from the one in mice (Wordinger et al., 1993) and bovines (Fair \& Hyttel, 1997; Fair et al., 1997). The existence of desmosome junctions between the oolemma and the follicular cells, the appearance of microvilli in primordial follicle, their location in the zona pellucida as well as their progressive enlargement, are comparable with the reported in other mammals (Suprasert et al., 1989; Falconnier \& Kress, 1992; Motta et al., 1994, 1995; Grøndahl et al., 1995; Fair \& Hyttel, 1997; Fair et al., 1997).

The ultrastructural characteristics of follicular cells are typical of mammals nevertheless the presence of fewer mitochondria in the tertiary follicle and their rounded shape in all stages, are remarkable features in $C$. villosus and clearly different from other studied species (Suprasert $e t$ al., 1989; Falconnier \& Kress, 1992; Roy, 1994). The development of the theca is similar to that described for Dasypus novemcinctus (Enders \& Buchanan, 1959).

The growth of oocyte and follicle established in C. villosus, conforms to the typical biphasic pattern found in eutherian mammals and some marsupials (Lintern-Moore et al., 1976; Wassarman, 1988; Rodger et al., 1992; Monniaux et al., 1997). The observation that in C. villosus the oocyte completes its growth in the tertiary follicle is similar to other species (Lintern-Moore et al., 1976; Monniaux et al., 1997). Although, the maximum diameters of oocyte and follicle are larger than those referred to for placentalia (Lintern-Moore et al., 1976), oocyte size agrees with the range established by Gomendio \& Roldán (1994). The mean diameter of Graafian follicles in C. villosus seems to be smaller than that reported for Dasypus novemcinctus (Newman, 1912; Peppler \& Canale, 1980; Peppler et al., 1986). The evidence provided in this work shows that the structure of ovarian follicles in C. villosus is essentially similar to that in other mammalian species. Knowledge of folliculogenesis in the ovary of the armadillo may contribute to a better comprehension of the reproductive biology of these primitive animals. Furthermore, assuming their importance as biomedical models, it may constitute a clear aid to their maintenance in captivity.

Acknowledgments - The assistance of Lic. Ricardo Camina in the statistical analysis is gratefully acknowledged. The study was supported by a Grant from the SGCYT (UNS). Dra. E. B. Casanave is member of the Research Career of the Consejo Nacional de Investigaciones Científicas y Técnicas (Conicet), Argentina.

\section{REFERENCES}

AFFANNI, J. M., CASANAVE, E. B., GARCÍA SAMARTINO, L. \& FERRARI, R., 1986, Neocortical and olfactory bulb activity in armadillos submitted to covering with soil. Arch. Int. Physiol. Biochem., 94: 271-279.

AFFANNI, J. M., GARCÍA SAMARTINO, L., CASANAVE, E. B. \& DEZI, R., 1987, Absence of apnea in armadillos covered with soil. Respirat. Physiol., 67: 239-242.

CASANAVE, E. B. \& AFFANNI, J. M., 1994, Body temperature of the armadillo Chaetophractus villosus (Mammalia, Dasypodidae). Arch. Int. Physiol. Biochim. Biophys., 102: $243-246$

CASANAVE, E. B. \& POLINI, N. N., 1999, Comparative study of some haematological parameters of two wild population of Chaetophractus villosus (Mammalia, Dasypodidae). Comp. Haematol. Int., 9(1): 13-16.

CODÓN, S. M. \& CASANAVE, E. B., 1996, Histology of the ovary of the armadillo Chaetophractus villosus (Mammalia, Dasypodidae). Rev. Brasil. Biol., 56(3): 599-604.

ENDERS, A. C., 1960, A histological study of the cortex of the ovary of the adult armadillo, with special reference to the question of neo formation of oocytes. Anat. Rec., 136: 491-499.

ENDERS, A. C., 1966, The reproductive cycle of the ninebanded armadillo Dasypus novemcinctus. Symp. Zool. Soc. Lond., 15: 295-310.

ENDERS, A. C. \& BUCHANAN, G. D., 1959, The reproductive tract of the female nine-banded armadillo. Texas Rep. Biol. Med., 17(3): 323-340.

ENGELMANN, G. F., 1985, The phylogeny of the Xenarthra. pp. 51-64. In: G. G. Montgomery (ed.), The evolution and ecology of Armadillos, Sloths and Vermilinguas, Smithson. Inst. Press., Washington, D.C. 
FAIR, T., HULSHOF, S. C. J., HYTTEL, P., GREVE, T. \& BOLAND, M., 1997, Oocyte ultrastructure in bovine primordial to early tertiary follicles. Anat. Embryol. 195: $327-336$.

FAIR, T. \& HYTTEL, P., 1997, Oocyte growth in cattle. Ultrastructure, transcription and developmental com petence, pp. 109-118. In: P. M. Motta (ed.), Microscopy of Reproduction and Development: A Dynamic Approach. Antonio Delfino Editore, Roma.

FALCONNIER, C. \& KRESS, A., 1992, Ultrastructural aspects of oocyte growth in the marsupial Monodelphis domestica (grey short-tailed opossum). J. Anat., 181: 481-498.

FERNÁNDEZ, M., 1909, Beitraege zur embryologie der güerteltiere. I. Zur keimblaetterrinversion und spezifischen polyembryonie der mulita (Tatusia hybruda). Morph. Jahrb. Bd., 39: 302-333.

GARCÍA SAMARTINO, L., AFFANNI, J. M., CASANAVE, E B., FERRARI, R. \& IODICE, O., 1987, On the presence of a peculiar alpha rhythm in the olfactory tubercle of waking armadillos. EEG. Clin. Neurophysiol., 66: 185-190.

GOMENDIO, M. \& ROLDÁN, E. R. S., 1994, The evolution of gametes. pp.115-151. In: E. E. Bittar \& N. Bittar (eds.), Principles of medical biology. Vol. 1B. Evolutionary biology. J. A. I. Press. Inc., Greenwich, Connecticut.

GRASSÉ, P. P., 1955, Ordre des Edéntés. pp. 1182-1266. In: P. P. Grassé (ed.), Traité de zoologie. Vol. XVII (2). Masson et Cie., Paris.

GRØNDAHL, C., HYTTEL, P., GRØNDAHL, M. L., ERIKSEN, T., GOTFREDSEN, P. \& GREVE, T., 1995, Structural and endocrine aspects of equine oocyte maturation in vivo. Mol. Reprod. Dev., 42: 94-105.

KIRCHHEIMER, W. F. \& STORRS, E. E., 1971, Attempts to establish the armadillo (Dasypus novemcinctus, Linn.) as a model for the study of leprosy. I. Report of lepromatoid leprosy in an experimentally infected armadillo. Int. J. Lepr., 39: 692-702.

LINTERN-MOORE, S., MOORE, G. P. M., TYNDALEBISCOE, C. H. \& POOLE, W. E., 1976, Growth of oocyte and follicle in the ovaries of monotremes and marsupials. Anat. Rec., 185: 325-332.

MAITLAND, P. \& ULLMANN, S. L., 1993, Gonadal development in the opossum, Monodelphis domestica: the rete ovarii does not contribute to the steroidogenic tissues. $J$. Anat., 183: 43-56.

MC NAB, B. K., 1984, Energetics and the limits to a temperate distribution in armadillos. J. Mammal., 61: 606-627.

MONNIAUX, D., HUET, C., BESNARD, N., CLÉMENT, F., BOSC, M., PISSELET, C., MONGET, P. \& MARIANA, J. C., 1997, Follicular growth and ovarian dynamics in mammals. J. Reprod. Fert., 51: 3-23.

MOTTA, P. M., MAKABE, S., NAGURO, T. \& CORRER, S., 1994, Oocyte follicle cells association during development of human ovarian follicle. A study by high resolution scanning and transmission electron microscopy. Arch. Histol. Cytol., 57(4): 369-394.

MOTTA, P. M., NOTTOLA, S. A., FAMILIARI, G. MACCHIARELLI, G., VIZZA, E. \& CORRER, S., 1995, Ultrastructure of human reproduction from folliculogenesis to early embryo development. A review. It. J. Anat. Embriol., 100: 9-72.
NEWMAN, H. H., 1912, The ovum of the nine-banded armadillo: growth of the ovocytes, maturation and fertilization. Biol. Bull., 23: 100-141.

NEWMAN, H. H. \& PATTERSON, J. T., 1909, A case of normal identical cuadruplets in the armadillo and its bearing on the problem of identical twins and sex determination. Biol. Bull., 17: 181-187

PEDERSEN, T. \& PETERS, H., 1968, Proposal for a classification of oocytes and follicles in the mouse ovary. $J$. Reprod. Fertil., 17: 555-557.

PEPPLER, R. D. \& CANALE, J., 1980, Quantitative investigation of the annual pattern of follicular development in the nine-banded armadillo (Dasypus novemcinctus). J. Reprod. Fertil., 59: 193-197.

PEPPlER, R. D., HOSSLER, F. E. \& STONE, S. C., 1986, Determination of reproductive maturity in the female ninebanded armadillo (Dasypus novemcinctus). J. Reprod. Fert., 76: 141-146.

POLINI, N., CAMINA, R. \& CASANAVE, E. B., 1999, Morphological and morphometrical study of the blood leucocytes from Chaetophractus villosus, Mammalia, Dasypodidae. Comp. Haematol. Int., 9(3): 162-167.

RAYNAUD, A., 1969, Organes génitaux des mammifères placentaires. pp. 453-636. In: P. P. Grassé (ed.), Traité de Zoologie. Vol. XVI (6). Masson et Cie., Paris.

REDFORD, K. H. \& EISENBERG, J. F., 1992, Order Xenarthra (Edentata). pp. 46-68. In: K. H. Redford \& J. F. Eisenberg (eds.), Mammals of the Neotropics. Vol. 2. The Southern Cone. University of Chicago Press, Chicago.

RODGER, J. C., GILE, S. I. \& MATE, K. E., 1992, Unexpected oocyte growth after follicular antrum formation in four marsupial species. J. Reprod. Fert., 96: 755-763.

ROY, S. K., 1994, Regulation of ovarian follicular development: A review of microscopic studies. Microsc. Res. Tech., 27: 83-96.

SOKAL, R. R. \& ROHLF, F. J., 1981, Biometry. 2. ed. Freeman, New York, 859p.

STORRS, E. E., 1971, The nine-banded armadillo: a model for leprosy and other biomedical research. Int. J. Lepr., 39: 703-714.

SUPRASERT, A., HIRUNAGI, K., FUJIOKA, T. \& YOKOYAMA, A., 1989, Histochemistry of glycoconjugates in ovarian follicles of the adult house musk shrew, Suncus murinus. Acta Anat., 136: 269-278.

TALMAGE, R. V. \& BUCHANAN, G. D., 1954, The armadillo (Dasypus novemcinctus). A review of its natural history, ecology, anatomy and reproductive physiology. Rice. Inst. Pamphlet., 41(2): 1-135.

TAULMAN, J. F. \& ROBBINS, L. W., 1996, Recent range expansion and distributional limits of the nine-banded armadillo (Dasypus novemcinctus) in the United States. J. Biogeography, 23: 635-648.

WASSARMAN, P. M., 1988, The mammalian ovum. pp. 69102. In: E. Knobil \& J. D. Neill (eds.), The phisiology of reproduction. Vol. 1. Raven Press, New York.

WORDINGER, R. J., BRUN-ZINKERNAGEL, A. M. \& CHANG I-F. C., 1993, Immunohistochemical localization of basic fibroblast growth factor (bFGF) within growing and atretic mouse ovarian follicles. Growth Factors, 9: 279289. 